
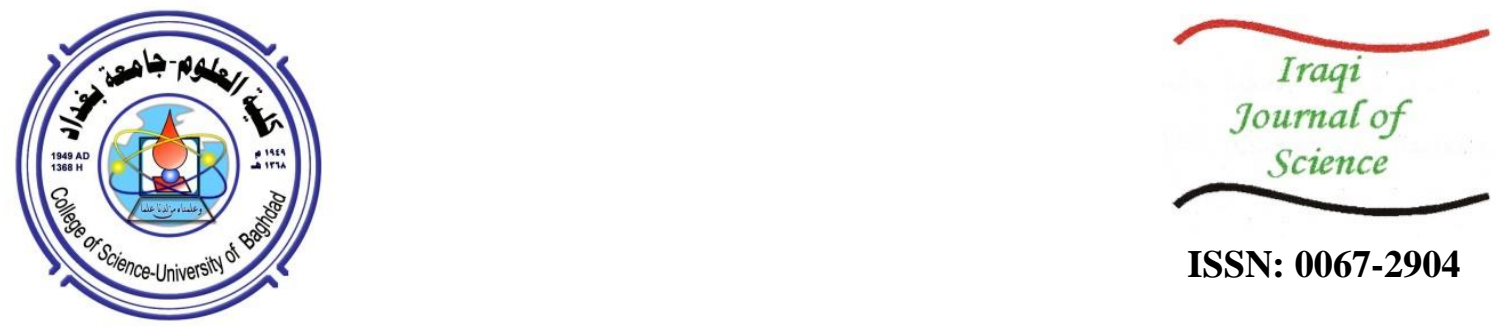

ISSN: 0067-2904

\title{
Delineation the effect of saline groundwater on the resistivity of middle part of Dammam Formation southwest of Samawah city, Southern Iraq
}

\author{
Abdullah A. AL-Juboury ${ }^{1 *}$, Jassim M. Thabit ${ }^{1}$, Firas H. AL-Menshed ${ }^{2}$ \\ ${ }^{1}$ Department of Geology, College of Science, Baghdad University, Baghdad, Iraq. \\ ${ }^{2}$ The General Commission for Ground Water, Baghdad, Iraq.
}

\begin{abstract}
The study area intendes for agricultural investment and establishment stations of water pumping for human use to the nearby areas, southwest of Samawah city. Twelve Two-Dimension (2-D) survey points were performed by using WennerSchlumberger array configuration to take the measurements. The inverse models of two survey point appear the effect of the saline groundwater that raises from Rus Formation, which caused a significant reduction in resistivity of the groundwaterbearing zone within middle Dammam Formation along the fault plane.
\end{abstract}

Keywords: aquifers, Electrical survey, 2-D resistivity imaging, saline groundwater, Dammam Formation, Rus Formation, Wenner- Schlumberger array, Samawah city.

$$
\begin{aligned}
& \text { الكشف عن تأثير المياه المالحة على مقاومة الجزء الوسطي من تكوين الامام جنوب غرب مدينة } \\
& \text { السماوة، جنوب العراق، باستخدام مست المقاومة التصويري ثنائي الأبعاد }
\end{aligned}
$$

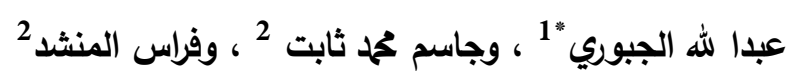

$$
\begin{aligned}
& \text { اقسم علم الأرض، كلية العلوم، جامعة بغداد، بغداد، العراق. } \\
& \text { 2الكيئة العامة للمياه الجوفية، بغداد، العراق. }
\end{aligned}
$$$$
\text { الخلاصة: }
$$$$
\text { تعد منطقة الدراسة كمنطقة واعدة للاستثمار الزراعي ولنصب مضخات المياه الصالحة للاستخدام البشري }
$$$$
\text { للمناطق القريبة من منطقة الدراسة جنوب غرب مدينة السماوة. نفذ المسح باخذ القياسات في اثنتي عشرة نقطة }
$$$$
\text { قياس بترتيب فنر -شلمبرجر. أظهرت اثثين من الموديلات المعكوسة لنقاط المسح ثنائي البعد تأثير المياه }
$$$$
\text { الجوفية المالحة والصاعدة من تكوين الرص والتي أدت الى انخفاض كبير في مقاومة النطاق الخامل للمياه }
$$

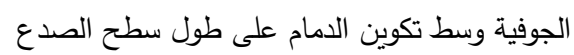

\section{Introduction}

The study area is located at south-west of Samawah city, locally called Shghatia ( $\mathrm{SH})$ as shown in Figure 1. It is intended for agricultural investment and establishing stations of water pumps to meet the requirements of nearby areas. The aim of this study is delineating saline groundwater that raises from Rus Formation to avoid drilling wells at the position that appears these effect. The electrical survey considers the most important method used to definition and study of the groundwater aquifers [1]. The principle of resistivity survey method is based on the physical ohm's law $(\mathrm{R}=\Delta \mathrm{V} / \mathrm{I})$, which governs the flow of the electrical current within a metal wire $[1,2]$, Where $\mathrm{R}$ is the resistance, $\Delta \mathrm{V}$ is the potential difference across the wire, and I is the electric current passes through this resistance. The measurements are practices by injected the DC electric current in the ground by a pair of current source and measured the potential difference at the other pair of potential electrode $[1,3]$. The Electric 
current flows through earth materials at shallow depth by two main methods [2, 4]. The first is electronic conduction, by this method the current flows via free electrons such as through metals. The second is electrolytic conduction, by this method the current flows by movement the ions in groundwater, which is a more common mechanism in engineering and environmental surveys [3].

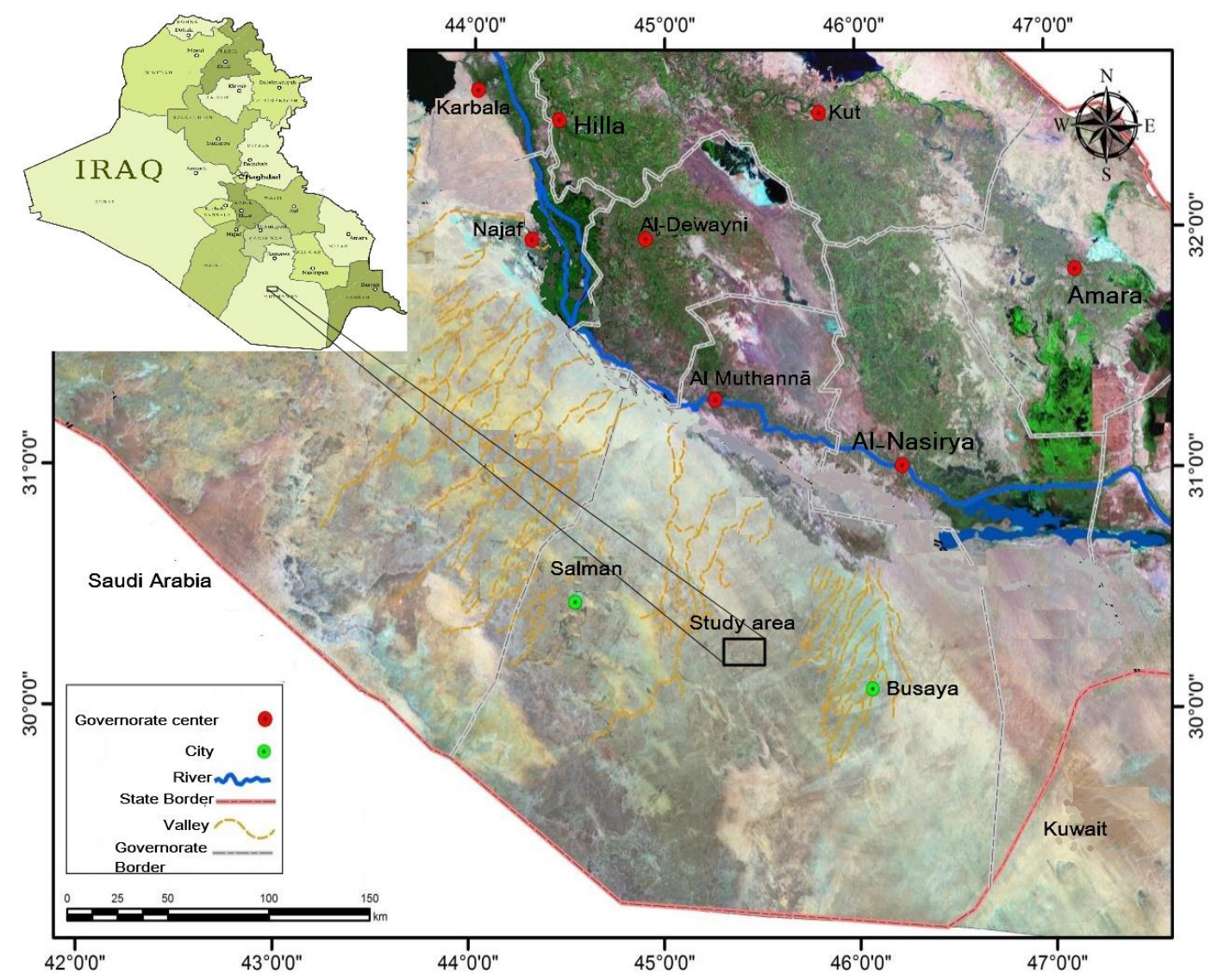

Figure 1- location of the study area.

\section{Geological and Hydrologic setting}

The survey area is part of the desert zone [5]. It located within one of the hydrogeological basing in the southern desert of Iraq (Shbecha-Al Salman basin) [5, 6]. The Dammam Formation consider as the most imported geological Formation that contains aquafers of groundwater in Samawah desert [7]. Many of wells are drilled by General Commission for Groundwater near the survey point SH1and SH10, as be shown in Figure- 2. The water level of these wells is ranging between 70-75 m, with electrical conductivity ranging between 3150-6000 micro Mohslcm [8]. The survey area is characterized by existence the hills of fragments of limestone (outcrops of Dammam Formations) alternate with flat and depressions areas that filled by quaternary deposition (clastic soil that consists of clay and silt with secondary gypsum) [7, 9]. The fluctuation in chemical and physical weathering processes along the Quaternary period produced these features and structures of the earth's surface, in addition, weakly of rainfall and absence of vegetation covers [10]. These flat and depressions areas extend from many squire kilometers to several hundreds of square kilometers [10], which have important investment and agricultural purposes. The surface of the study area is covered mainly by tertiary and quaternary deposits $[11,12]$. The tertiary deposits represented by

A- Rus Formation (Lower Eocene), which deposited under hot and evaporate condition (lagoon environmental). It consists mainly of thick beds of gypsum and anhydrite interbedded with marl and marly Limestone beds $[8,13]$. The Rus Formation consider as hydrogeology unit and has a thickness ranging between 20-50 m [7]. It does not exposit in the survey area. According to the General Commission for Ground Water (G.C.G.W); it probably is reached by deeper wells (more than $200 \mathrm{~m}$ ) [14]. 
B- Dammam Formation (Upper- Middle Eocene), which consider as one most important of groundwater-bearing zone in the southwest of Iraq [15]. It exposed in most of the survey area. The middle Dammam Formation characterized by the existence of karstified canals, cavities, fissures and joints, and fractures, which make it with high permeability and transmissivity $[8,16]$.

The Quaternary deposits are covers whole of the survey area, except Dammam Formation outcrops. It represented by younger and older alluviums of depression-filling deposits, slope deposits and valleyfilling deposits [13]. The quaternary deposits consist mainly of clay or mud, silt, silty clay, and sand, in addition to secondary gypsum [17]. It has variable thickness and characterizes by low resistivity because of clay mineral contain (the resistivity is ranging between $2.00-4.5 \mathrm{ohm} . \mathrm{m}$ )

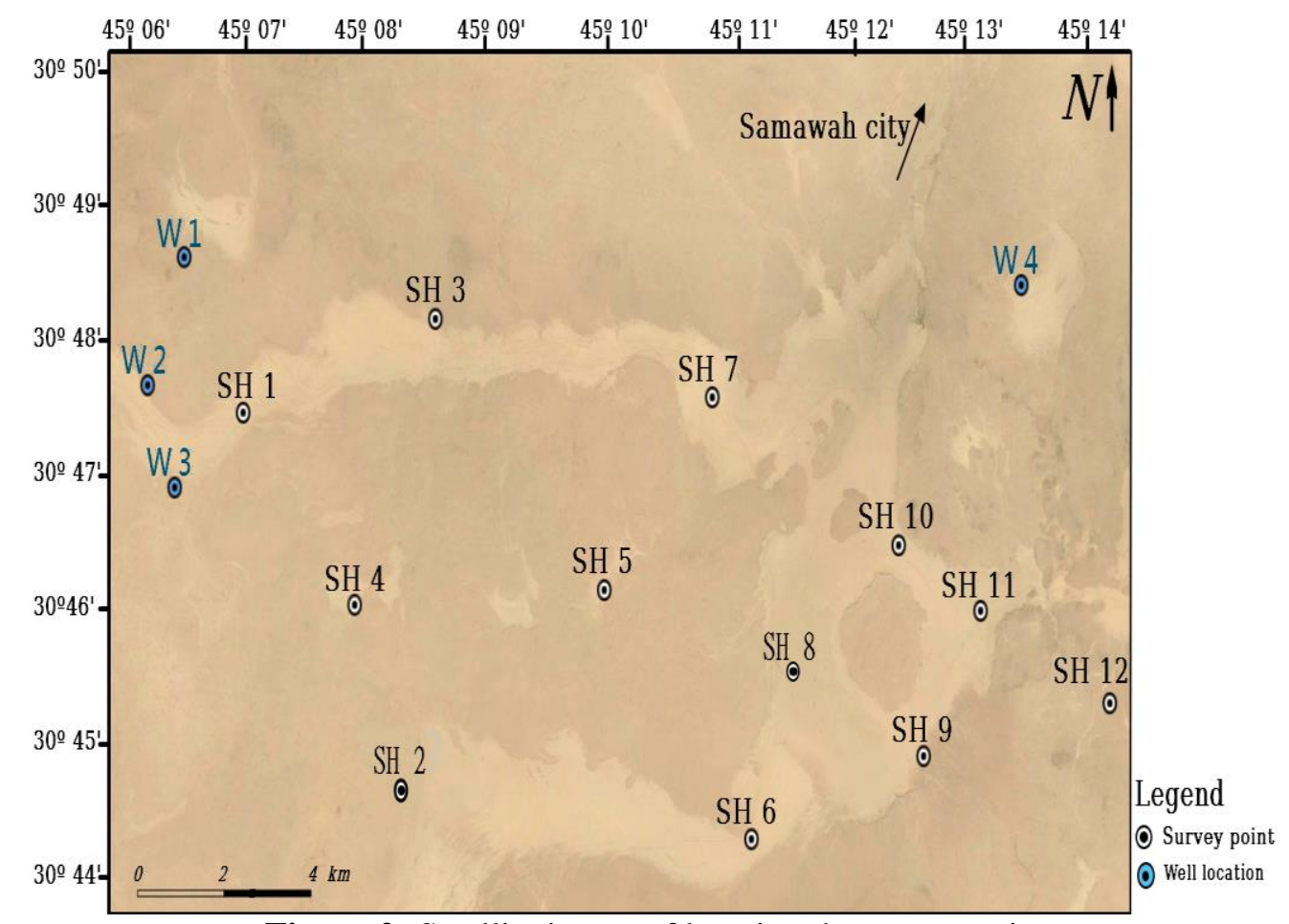

Figure 2- Satellite image of location the survey point.

\section{Field data}

The Wenner-Schlumberger array is used to carry out 2-D resistivity imaging survey in this study. The sequences of measurements are created by using ELECTRE pro software [12]. The study area is achieved by conducting twelve survey points. Location and distribution of the survey points within the survey area depend on the width of the flat area. The length of the array line in each survey point is 1200 meters; by using 120 electrodes, with 10 meters electrode spacing. The estimated depth of investigation in each survey points is reached to 225 meters. Except for the survey point SH 5, which performed by using only 100 electrodes, because of the survey area is narrow and restricted by Dammam Formation outcrops. The estimated depth of investigation reaches to $190 \mathrm{~m}$. The direction of the array lines in each survey points is northeast-southwest, which perpendicular on the layer's slop [1, 18] to get depth with a true thickness of these layers [19].

\section{Data processing}

The field data are processed and the bad data is removed in several stages after completing the fieldwork by using PROSYS II and RES2DINV programs $[13,14,15]$. The automatic filter is used instead of the manual filter with PROSYS II program. The RES2DINV program used to remove bad data into two stages. The first stage by picking out the bad data in profile form. The second stage by moving out green line to the left side of the small percent of datum point bare (less than 20\%) before repeated the inverse subroutine iteration to reduce the RMS error ratio (Figure- 3). After finishing of removal bad data, the field data being of high quality, which reflects the distribution of the subsurface resistivity [3]. 


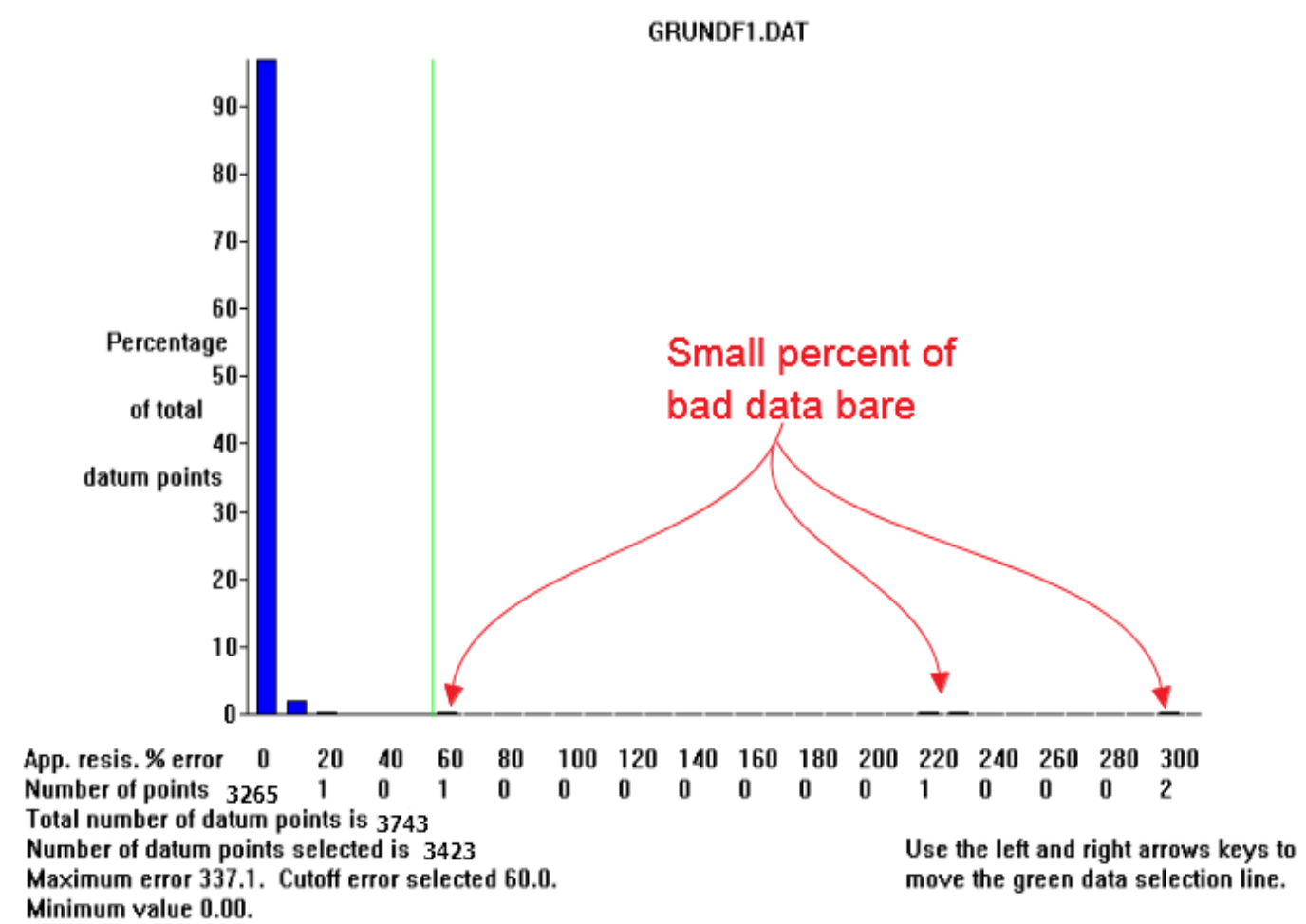

Figure 3- The bar chart of datum point percent of the SH 1.

The RES2DINV software intended to invert a large number of set data (reach to 21000 data) that provided by a great number of electrodes (more of 25 electrodes) [5]. Therefore, it used to interpret the field data. The RES2DINV program built up to run as much as possible in a powerful and automatic manner by modifying many of default control parameters on the field data to fine-tune the inversion subroutine operation. The initial value that used with damping filter is $(0.2)$ and the minimum value is (0.02), because of the survey area consist of semi horizontal layers and far away from the noise sources.

\section{Results and discussion}

The inverse models of the survey points show there are three main resistivity zones (Figures- 4, 5).

- The resistivity of the first zone is ranging between $2.00-4.50 \mathrm{ohm} . \mathrm{m}$, which represented the shallow depth of the inverse models (blue color in the inverse models). Except for the inverse model of survey point SH 2 and SH 8 that located at deeper layers, which represented the effect of saline groundwater that raising from Rus Formation. The low resistivity at shallow zone represents the quaternary deposits. It consists mainly of clay, silt and secondary gypsum that have high conductive because of clay minerals contain [8].

- The resistivity of the second zone is ranging between $10.1-51.3 \mathrm{ohm} . \mathrm{m}$, which represents the groundwater-bearing zone (green color in the inverse models). It located mainly within the middle part of Dammam Formation, which consists of carbonic rocks. 

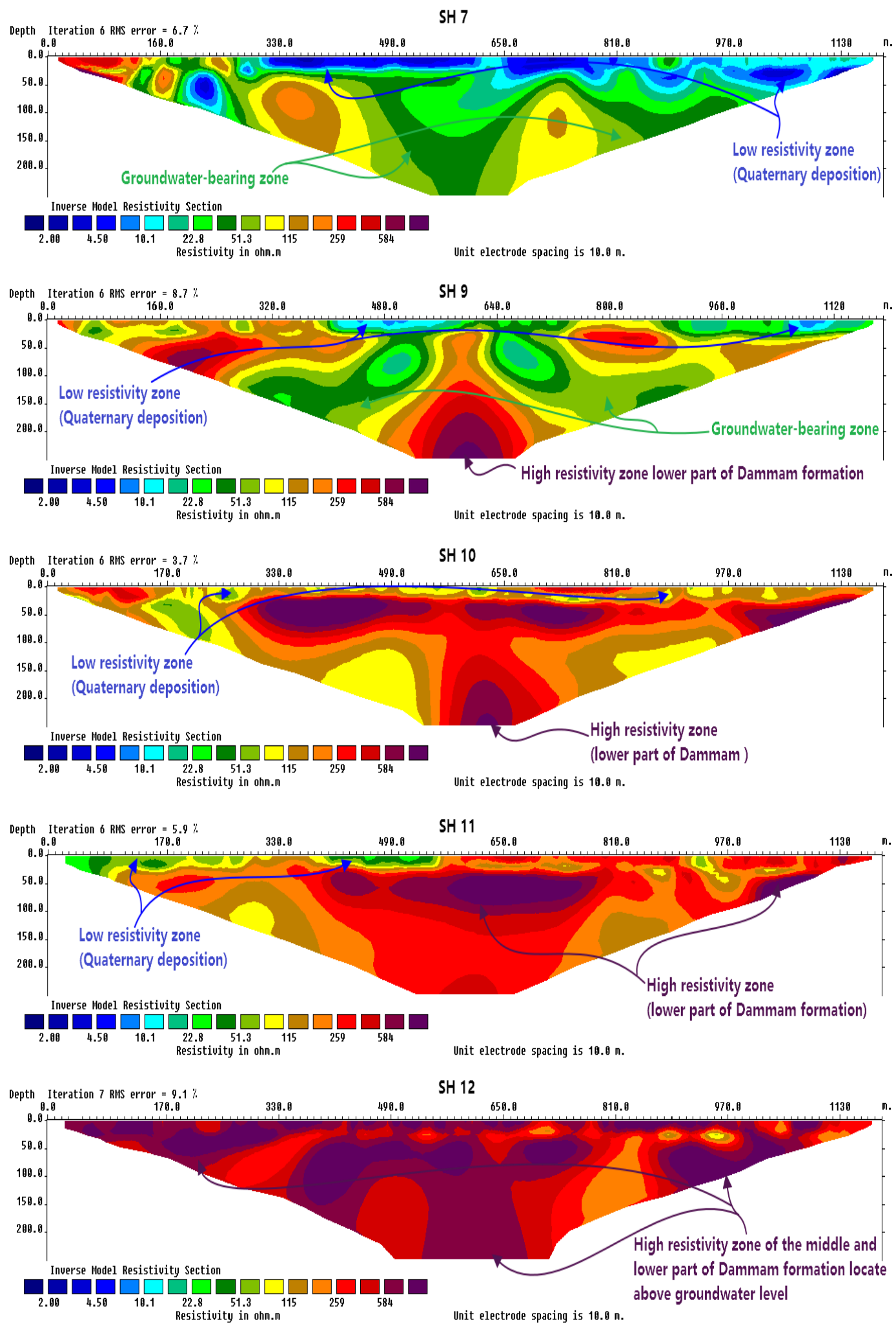

Figure 4- Inverse models of the survey points SH 1, SH 3, SH 4, SH 5 and SH 6.

The third resistivity zone is more than $115 \mathrm{ohm} . \mathrm{m}$ (red with purple color in the inverse models). It located mainly at deep inverse models, which represents the lower part of Dammam Formation that consist mainly of dolomite and dolomitic limestone. The inverse models in the eastern side of the study area (the survey points SH 10, SH 11 and SH 12) shows it has high resistivity compare with the other inverse models as be shown in Figure- 6. It may result of finding the middle part of Dammam 
Formation above water level and the lower Dammam Formation is raised at shallow depth, which consists mainly of dolomite and dolomitic limestone (the resistivity of dolomite is higher than limestone compare with the other inverse models as be shown in Figure-6. It may result of finding the shallow depth, which consists mainly of dolomite and dolomitic limestone (the resistivity of dolomite is higher than limestone [13]).
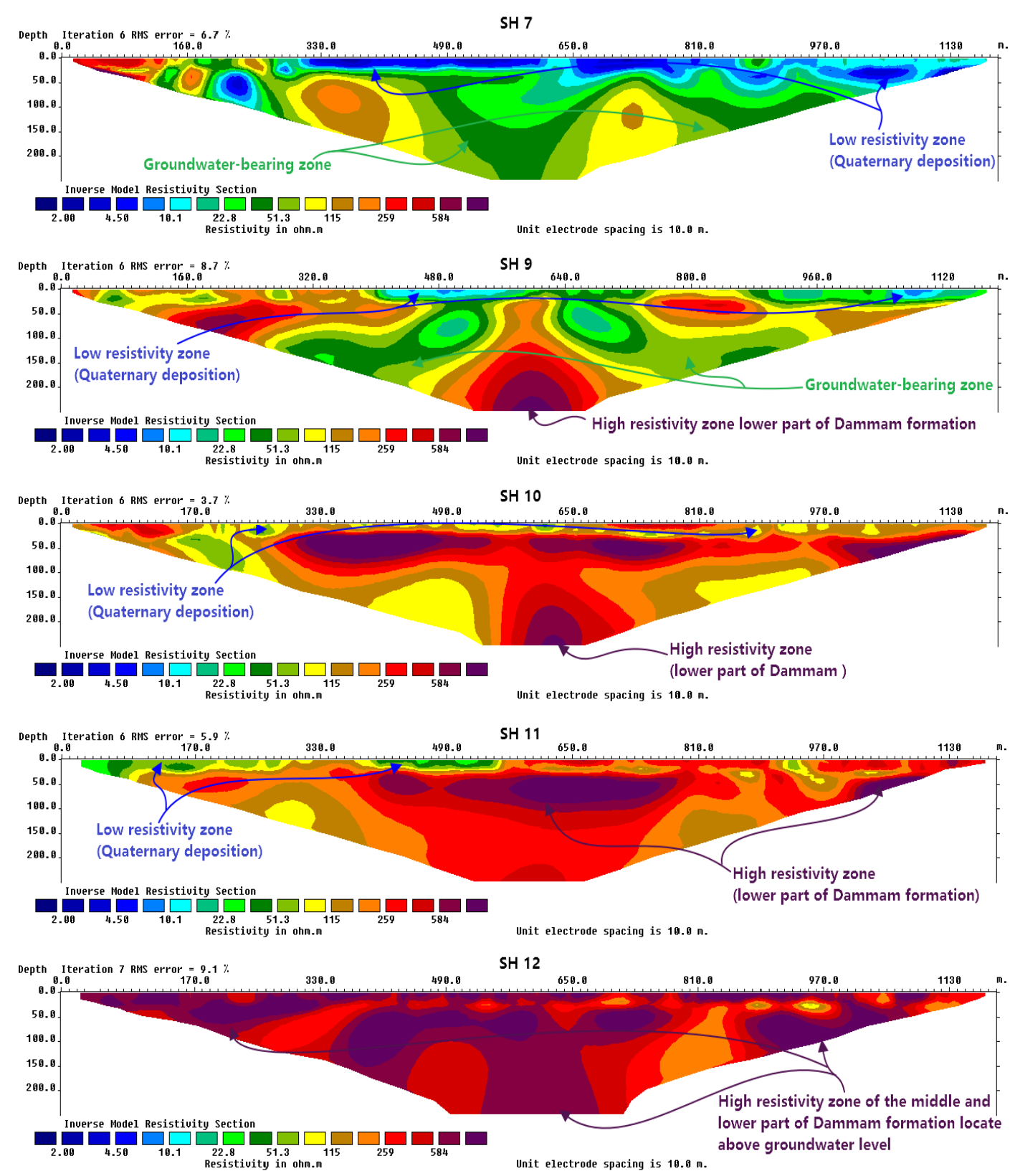

Figure 5- Inverse models of the survey points SH 7, SH 9, SH 10, SH 11, and SH 12.

When comparing the survey points in the study area, the survey point SH 2 and SH 8 showed low resistivity zone at deeper layers of the inverse model as be shown in Figures- 6 and 7. As a result of raising the saline groundwater from Rus Formation, which has low resistivity (the resistivity is ranging between $2.00-4.50 \mathrm{ohm} . \mathrm{m}$ ). The saline groundwater is raising with deep faults, which makes as a passageway of saline groundwater between Rus Formation and Dammam Formation. 

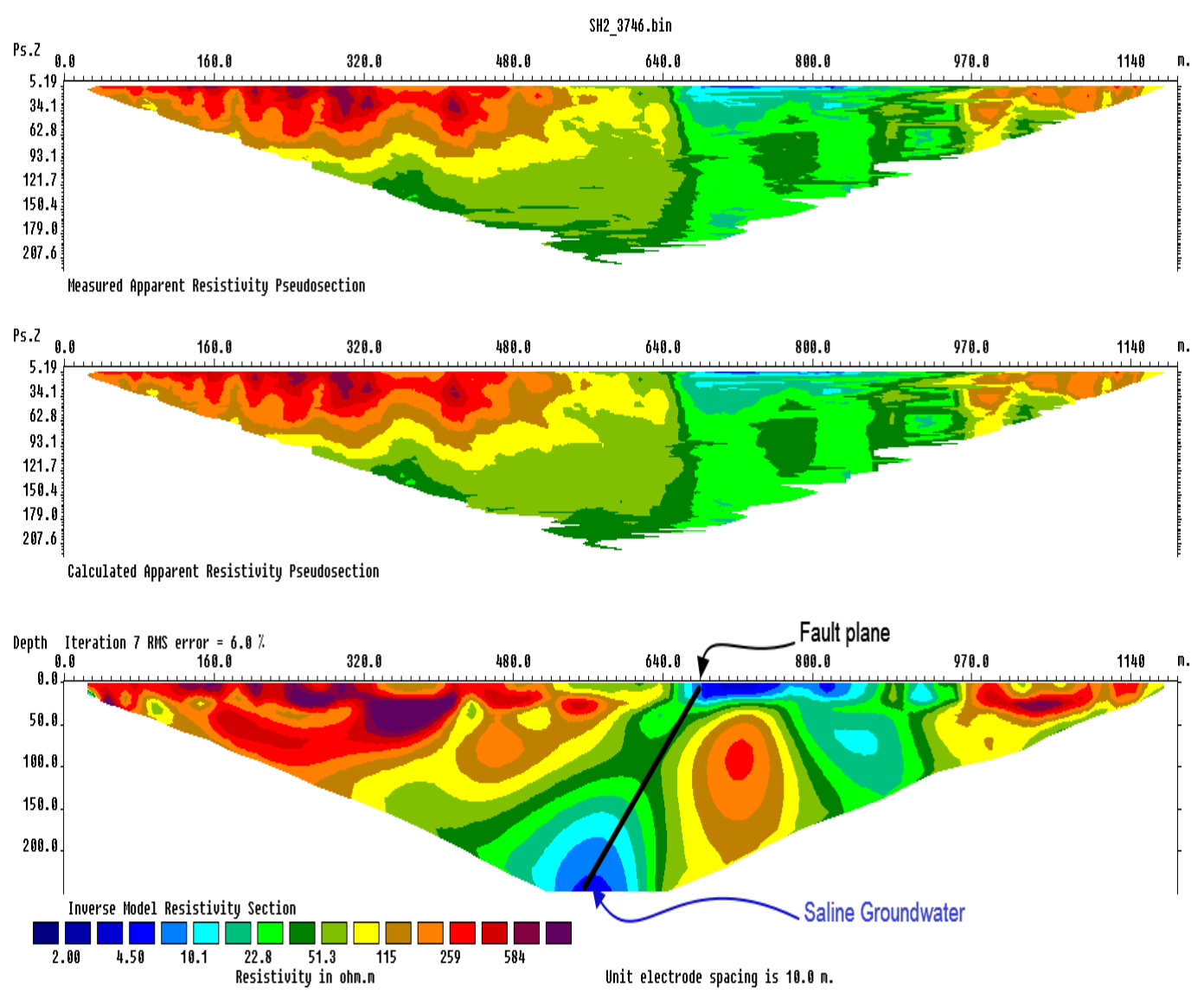

Figure 6- Inverse model with measured and calculated pseudosection of the survey point SH 2.
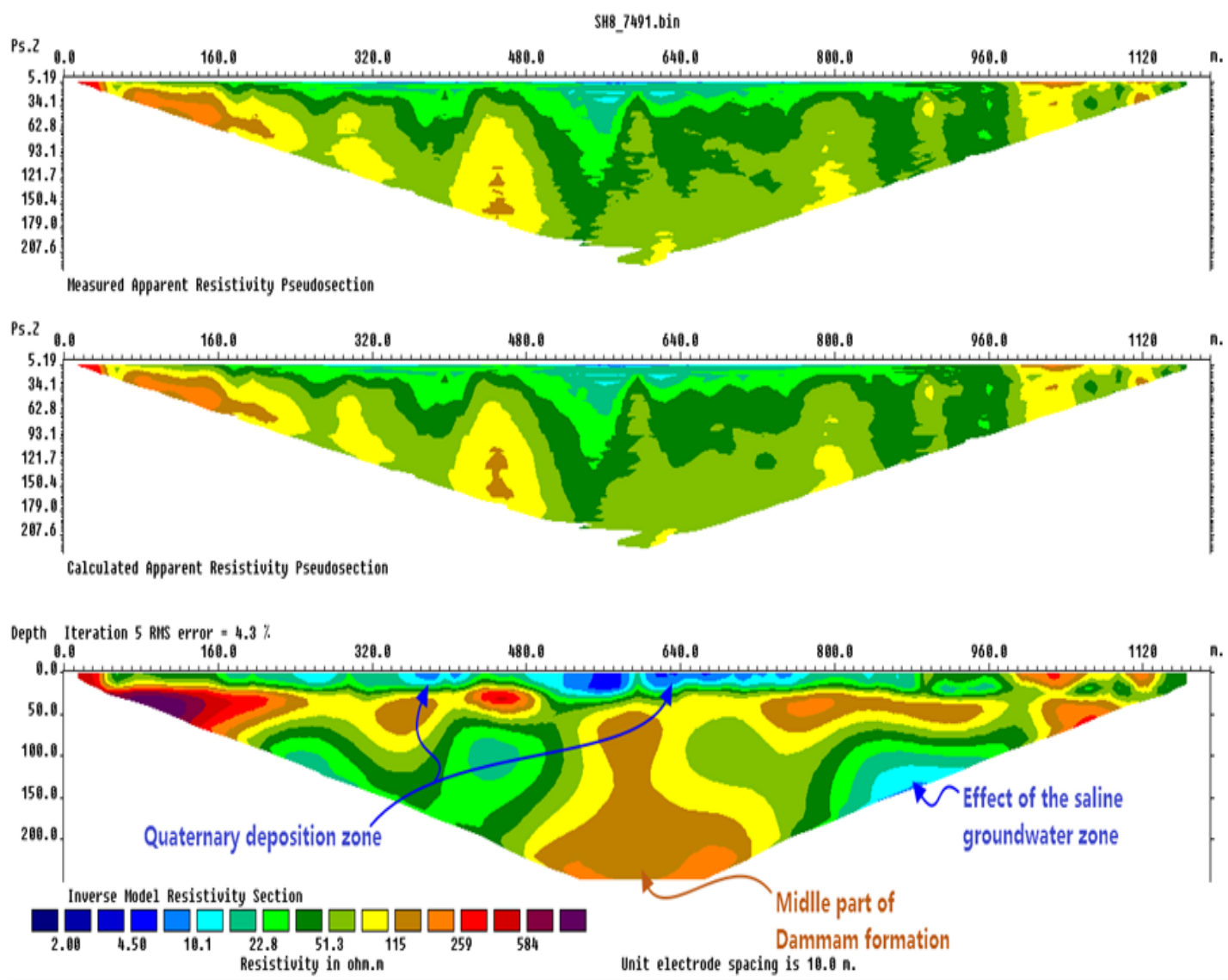

Figure 7- Inverse model with measured and calculated pseudosection of the survey point SH 8. 
The saline groundwater caused a significant reduction in resistivity of middle Dammam Formation. The survey point SH 2 shows the effect of saline groundwater at $200 \mathrm{~m}$ depth, under electrodes 52-61 along with the fault as shown in Figure-7.

The effect of deep fault is clearly appeared in the measured and calculated pseudosection of the survey point SH 2, by divided the high resistivity zone under electrodes $65-97$. The survey point SH 8 shows the effect the saline groundwater at $150 \mathrm{~m}$ depth, under electrodes 84-95 as shown in Figure-7. The estimate of resistivity zones in the survey area is explain by the Figure-8.

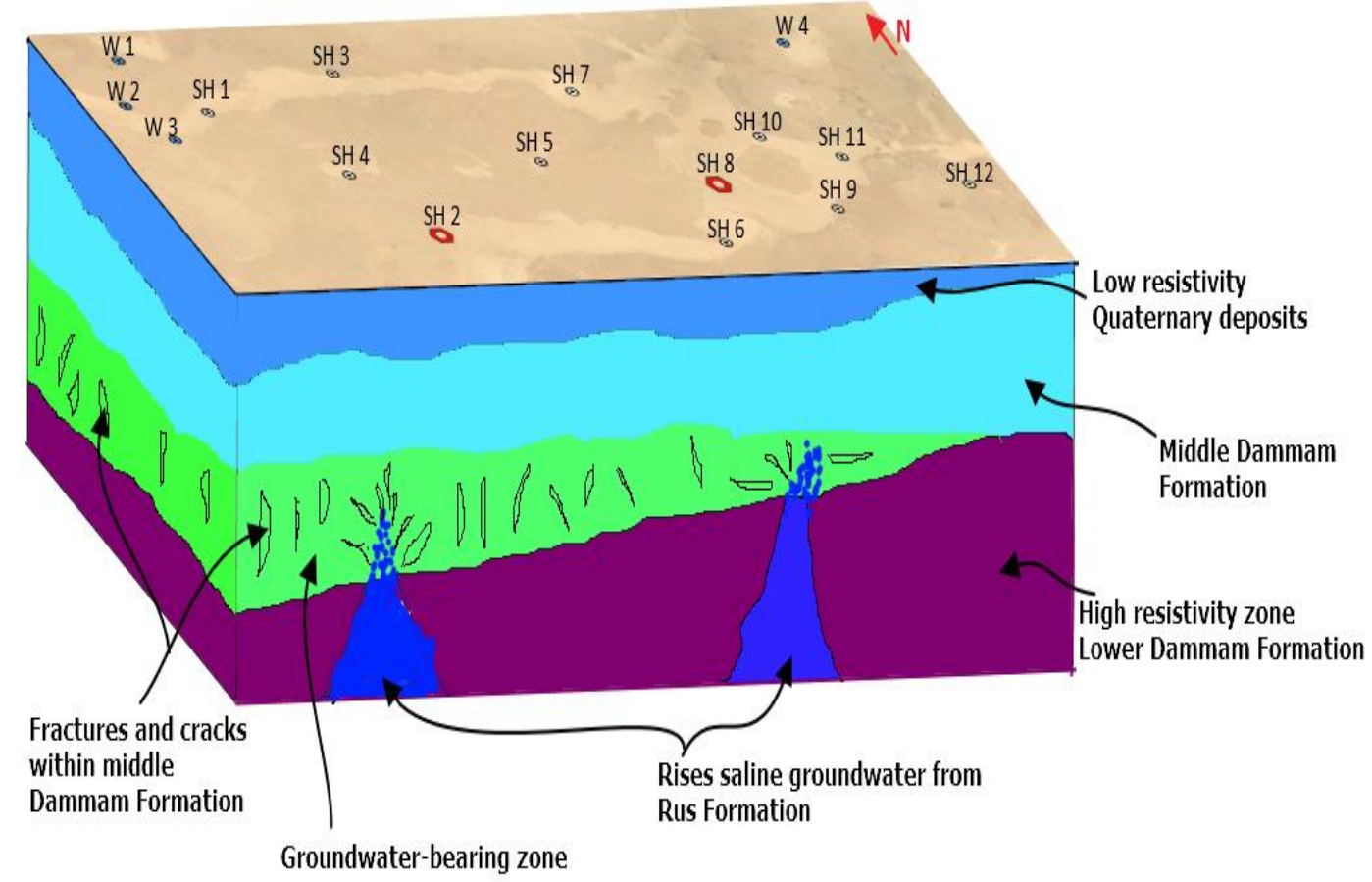

Figure 8- Sketch shows the estimate situation of the resistivity zones in the study area.

\section{Conclusions}

1. The Quaternary deposits characterized by low resistivity and have variable depth in the inverse models. Where the thickness is reduced at the eastern side compare with the western side of the study area as shown by the shallow low resistivity zone of the inverse models (the resistivity is ranging between 2.00-4.5 ohm.m).

2. The eastern side of the study area is characterized by high resistivity (more than $115 \mathrm{ohm} . \mathrm{m}$ ) compare with the western side, as being shown by the inverse models of the survey points SH10, SH 11 and SH 12. May result from locating the middle part of Dammam Formation above groundwater level with raise the lower part of Dammam Formation (consist mainly of dolomite and dolomitic limestone).

3. The saline groundwater that rises from Rus Formation within the middle part of Dammam Formation (groundwater-bearing zone) has clearly appeared in the survey points SH 2 and SH 8. It associated with the deep fault.

4. The thickness and depth of the groundwater aquifers vary between the surveys points according to the degree of the fractures and level depth of the middle part of Dammam Formation relative to the water level in the study area.

\section{Acknowledgments.}

The authors want to thanks General Director of the General Commission for Groundwater Mr. Dhafir Abdullah and geophysics department staff for provided the requirements to achieve the fieldwork and assisting me by providing the necessary information about the study area. 


\section{References}

1. Ramachandran K, Tapp B, Rigsby T, Erin L. 2012. Imaging of fault and fracture controls in the Arbuckle-Simpson Aquifer, Southern Oklahoma, USA, through Electrical Resistivity Sounding and Tomography Methods. Hindawi Publishing Corporation. Int J Geophys 2, Article ID 184836, 10.

2. Loke, M. H. 2004. Tutorial: 2-D and 3-D electrical imaging surveys.

3. Jassim M. Thabit and Ahmed S. Al-Zubedi. 2013. Aquifers delineation using vertical electrical sounding in south and southwest of Samawa city, southern Iraq

4. Loke MH, Chambers JE, Rucker DF, Kuras O, Wilkinson PP. 2013. Recent developments in the direct-current geoelectrical imaging method. J Appl Geophys, 95: 135-156.

5. Loke MH. 2016. Tutorial: $2 \mathrm{D}$ and $3 \mathrm{D}$ electrical imaging surveys. $207 \mathrm{p}$

6. Dahlin T, Zhou B. 2004. A numerical comparison of 2D resistivity imaging with 10 electrode arrays. Geophys Prospect, 52: 379-398.

7. Jassim M. Thabit \& Firas H. Khalid. 2016. Resistivity imaging survey to delineate subsurface seepage of hydrocarbon contaminated water at Karbala Governorate, Iraq.

8. Jassim M. Thabit \& Kassim A.AL-Tamimi. 2015. Delineation of Quaternary Aquifers by Using Long 2D Imaging in Southern Al-Shihaby Area (Wasit Governorate), Eastern Iraq.

9. Bose, R.N. and Ramkrishna, T.S. 1978. Electrical resistivity surveys for ground water in the Deccan traps country of Sangli district, Maharashtra. J. Hydro., 38: 209 - 221.

10. Andres KG, Canace R. 1984. Use of the electrical resistivity technique to delineate a hydrocarbon spill in the coastal plain deposits of New Jersey. In: Proceedings of the NWWA/API Conference on petroleum hydrocarbons and organic chemicals in ground water-prevention, detection and restoration, Houston, pp 188-197.

11. Bhattacharya, P.K., and Patra, H.P. 1968. Direct Current Geoelectrical Sounding, Elsevier Publishing Company, Amsterdam, 131pp.

12. Al-Mubarak, M., and R. M. Amin. 1983."Report on the regional geological mapping of the eastern part of the Western Desert and western part of the Southern Desert." GEOSURV, int. rep1380 (1983).

13. Bentley LR, Gharibi M. 2004. Two- and three-dimensional electrical resistivity imaging at a heterogeneous remediation site. Geophysics, 69: 674-680.

14. Crama, Yves, and Pierre Hansen. 1983. "An introduction to the ELECTRE research programme." Essays and surveys on multiple criteria decision-making. Springer, Berlin, Heidelberg, 1983. 31-42.

15. Dahlin T, Zhou B. 2001. A numerical comparison of $2 \mathrm{D}$ resistivity imaging with eight electrode arrays. In: Proceedings of the $7^{\text {th }}$ Meeting Environmental and Engineering Geophysics, Birmingham, England, 2-3 Sep, 2001. ELEMO1, p 2.

16. Geotomo Software. 2005. RES2DINV ver. 2.15. 2D/3D resistivity and IP inversion program. http://www.geoelectrical.com.

17. Jassim, Saad Z., and Jeremy C. Goff, 2006. eds. Geology of Iraq. DOLIN, SRO, distributed by Geological Society of London, 2006.

18. Mc Dowell PW. 1979. Geophysical mapping of water filled fracture zones in rocks. Int Assoc Eng Geol Bull, 19: 258-264.

19. Waierdy, N. W. 1994. "The Hydraulic characteristic of the Dammam Formation in the western desert of Iraq." Unpublished Ms. Thesis, College of Science, University of Baghdad, 144pp. 